\title{
PENGARUH EFISIENSI OPERASIONAL, EFEKTIVITAS PEMASARAN, DAN FINANCIAL LEVERAGE TERHADAP KINERJA KEUANGAN PERUSAHAAN
}

\author{
Viola Sahlan', Maswar Abdi \\ ${ }^{1}$ Program Studi Manajemen, Fakultas Ekonomi dan Bisnis, Universitas Tarumanagara \\ Email: viola_sahlan@yahoo.com \\ ${ }^{2}$ Program Studi Manajemen, Fakultas Ekonomi dan Bisnis, Universitas Tarumanagara* \\ Email: maxwar.untar@gmail.com \\ *Penulis Korespondensi
}

\begin{abstract}
ABSTRAK
Kinerja Keuangan mampu memberikan gambaran atas keberhasilan perusahaan dalam mencapai tujuannya. Kinerja keuangan diukur melalui ROE, dimana rasio tersebut menunjukan kemampuan perusahaan dalam meningkatkan keuntungan atas modal yang dimiliki pemegang saham / pemilik perusahaan. Dalam meningkatkan kinerja tersebut, efisiensi operasional, efektivitas pemasaran, dan financial leverage digunakan sebagai variabel yang mempengaruhi kinerja keuangan. Faktor-faktor tersebut diukur melalui rasio keuangan yaitu Expense to Sales sebagai alat ukur Efisiensi, Total Assets Turnover sebagai alat ukur Efektivitas, dan Debt to Equity Ratio sebagai alat ukur Financial Leverage. Penelitian ini dilakukan terhadap perusahaan subsektor farmasi yang terdaftar di BEI pada periode 20152019. Metode yang digunakan dalam melihat pengaruh variabel independen adalah analisis regresi berganda data panel dengan menggunakan perangkat lunak e-views 10.0. Hasil penelitian menunjukkan bahwa efisiensi operasional, efektivitas pemasaran, dan financial leverage memiliki pengaruh yang signifikan terhadap kinerja keuangan.
\end{abstract}

Kata Kunci: Expense to Sales (ES), Total Assets Turn Over (TATO), Debt to Equity (DER), Return On Equity $(R O E)$

\begin{abstract}
Financial performance is able to provide an overview of the company's success in achieving its objectives. Financial performance is measured through ROE, because the ratio shows the ability of the company in increasing the profit on capital owned by shareholders / owners of the company. In improving the performance, operational efficiency, marketing effectiveness, and financial leverage are used variables that effected the financial performance. These factors are measured through financial ratios of Expense to Sales as a measure of efficiency, Total Assets Turnover as a measure of Effectiveness, and Debt to Equity Ratio as a measure of Financial Leverage. This study was conducted on sub-sector pharmaceutical companies listed on the Stock Exchange in the period 2015 2019. The method used in determining the effect of independent variables is multiple panel data regression analysis using e-views 10.0 software. The results show that the operational efficiency, marketing effectiveness, and financial leverage have a significant effect on financial performance.
\end{abstract}

Keywords: Expense to Sales (ES), Total Assets Turn Over (TATO), Debt to Equity (DER), Return On Equity (ROE)

\section{PENDAHULUAN}

\section{Latar Belakang}

Suatu perusahaan didirikan dengan berbagai fungsi dan tujuan, antara lain untuk memperoleh laba atau keuntungan, memaksimalkan nilai saham, meningkatkan penjualan, meningkatkan pelayanan dan lain sebagainya (Brigham \& Ehrhardt, 2017). Faktor yang dapat mempengaruhi kinerja keuangan dapat berasal dari faktor eksternal maupun faktor internal perusahaan. Faktor 
internal tersebut dapat dianalisis dengan menggunakan analisis $D u$ Pont yang membahas tentang efisiensi, efektivitas, dan financial leverage.

Dalam analisis $D u$ Pont, terdapat tiga peran penting yang dibahas melalui analisis ini. Tiga peran tersebut terdiri dari efisiensi, efektivitas, dan financial leverage. Efisiensi adalah kemampuan perusahaan untuk melakukan pekerjaannya dengan benar, dimana para manajer menekan biaya atas sumber daya yang digunakan untuk mencapai tujuan perusahaannya yaitu untuk mendapatkan laba secara optimal. Oleh sebab itu, efisiensi memiliki peran penting dalam kegiatan operasional perusahaan dan akan berdampak pada kinerja keuangan perusahaan. Semakin efisien operasional perusahaan, maka laba yang dihasilkan perusahaan akan semakin besar (Drucker \& Collins, 2017).

Efektivitas merupakan kemampuan perusahaan dalam menggunakan alat ataupun asetnya dan mengolahnya secara baik dalam menghasilkan tingkat penjualan tertentu (Weidman, et al, 2018). Semakin efektif kegiatan yang dilakukan oleh perusahaan, maka akan semakin besar output yang dihasilkan oleh perusahaan dalam mencapai tujuannya.

Manajer keuangan perusahaan tersebut harus mampu memilih keputusan bagaimana cara perusahaan dalam mengumpulkan uang untuk mendanai investasinya. Pendanaan dapat dilakukan melalui dua cara, yaitu pembiayaan utang yang bersumber dari kreditor dan pembiayaan ekuitas yang bersumber dari investor. Hal ini tentunya menimbulkan pertanyaan bagi perusahaan apakah sebaiknya pendanaan dilakukan dengan melalui pembiayaan utang secara besar yang akan meningkatkan nilai perusahaan atau sebaliknya (Bhama, Jain, \& Yadav, 2016).

Sub sektor farmasi yang terdapat dalam sektor manufaktur menjadi salah satu sub sektor yang dilihat mempunyai potensi untuk dapat terus berkembang. Jika dilihat dari tingkat profitabilitas yang diproksikan dengan ROE, perusahaan pada sub sektor farmasi mengalami peningkatan maupun penurunan di setiap periodenya.

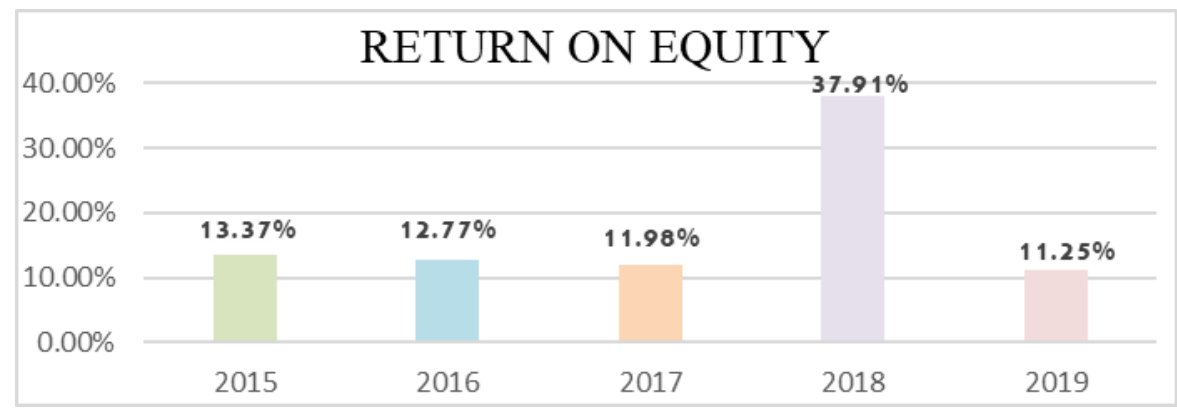

Gambar 1. ROE sub-sektor farmasi

Sumber: www.idx.co.id (data diolah oleh peneliti)

Melalui Gambar 1 dapat dilihat bahwa ROE yang terjadi pada perusahaan farmasi mengalami kondisi yang fluktuatif dan tentunya masih memiliki prospek yang cukup tinggi di masa yang akan datang. Kesempatan untuk mendapatkan lebih banyak peluang ini seharusnya dimanfaatkan oleh subsektor farmasi untuk terus meningkatkan nilai perusahaannya yang dapat diwujudkan melalui peningkatan kinerja keuangan dari perusahaan sub sektor farmasi di Indonesia. Berdasarkan latar belakang diatas, maka tujuan dari penelitian ini adalah untuk mengetahui pengaruh efisiensi operasional, efektivitas pemasaran, dan financial leverage terhadap kinerja 
keuangan perusahaan sub sektor farmasi yang terdaftar di Bursa Efek Indonesia periode 20152019.

\section{Kajian Teori \\ Dupont Identity}

Du Pont Analysis adalah analisis yang memperlihatkan bagaimana hutang, perputaran aktiva dan margin dikombinasikan untuk menentukan Return On Equity (ROE). Menurut Suad Husnan dan Enny Pudjiastuti (2012:80), mendefinisikan bahwa analisis Du Pont ini memusatkan analisis pada Return On Equity (ROE), dimana semakin tinggi ROE maka akan semakin baik tingkat pengembalian bagi pemilik ekuitas. Profit margin dikalikan total asset turnover maka akan menghasilkan return on asset (ROA). TATO membandingkan antara penjualan dengan total asset yang dimiliki perusahaan. Rasio ini menjelaskan bagaimana manajer perusahaan (pemasaran) dapat mengelola seluruh aktiva yang dimilikinya untuk dapat mendorong produktifitas dan mendongkrak profitabilitas dalam menghasilkan tingkat penjualan tertentu. Oleh karena itu, persamaan Du Pont dicerminkan oleh ROA yaitu merupakan hasil perkalian antara net profit margin dengan total assets turnover:

$$
\begin{aligned}
\text { ROA } & =\text { NPM } \times \text { TATO } \\
& =\frac{\text { Net Income }}{\text { Sales }} \times \frac{\text { Sales }}{\text { Total Assets }}
\end{aligned}
$$

Delen et al. (2013) menjelaskan bahwa efisiensi operasional dapat digambarkan oleh nilai rasio beban terhadap pendapatan yang mengukur tingkat beban atas pendapatan yang dihasilkan oleh perusahaan. Rumus dari Net Profit Margin dapat dipecah menjadi 1- expense to sales ratio sebagai berikut:

$$
\mathrm{NPM}=1-\text { expense to sales }
$$

Apabila perusahaan hanya menggunakan dana dengan equity (modal sendiri), maka tingkat keuntungan atas aset (ROA) dan tingkat keuntungan atas modal sendiri akan sama karena total aset sama dengan modal sendiri. Namun, apabila perusahaan menggunakan pendanaan dari leverage (hutang), maka modal sendiri akan lebih kecil dibandingkan dengan total aset, oleh karena itu ROE harus lebih tinggi dibandingkan dengan ROA. Semakin besar hutang akan semakin besar pula equity multiplier-nya. Maka dari itu, ROE sangat bergantung pada seberapa besar equity multiplier:

$$
\begin{aligned}
\mathrm{ROE} & =\quad \mathrm{ROA} \times \mathrm{EM} \\
& =\frac{\text { Net Income }}{\text { Total Asset }} \times \frac{\text { Total Asset }}{\text { Total Equity }}
\end{aligned}
$$

Ross et al. (2016) menjelaskan bahwa nilai rasio debt to equity dapat menggambarkan leverage yang merupakan besarnya risiko finansial yang muncul akibat pendanaan dari utang dimana DER membandingkan penggunaan sumber dana dari utang dan modal sendiri. Maka rumus dari equity multiplier dapat dipecah menjadi $1+$ DER sebagai berikut:

$$
\mathrm{EM}=1+\mathrm{DER}
$$

\section{Pecking Order Theory}

Gitman \& Zutter (2015) dalam bukunya menjelaskan mengenai teori pecking order dimana ketika perusahaan menentukan pendanaan eksternal, lebih diutamakan pembiayaan utang yang bersumber dari kreditur dibandingkan dengan pembiayaan ekuitas yang diperoleh melalui penerbitan saham baru karena dianggap memiliki risiko yang lebih tinggi jika dibandingkan dengan pembiayaan utang. Dalam pecking order theory dijelaskan bahwa biaya modal yang 
muncul melalui utang dianggap lebih rendah dibandingkan melalui saham. Perusahaan berusaha untuk mencari sumber dana dengan biaya dan risiko sekecil mungkin untuk mendanai kegiatan perusahaan.

\section{Penelitian Terdahulu}

Penelitian terdahulu yang dilakukan oleh Muchori pada tahun 2018 yang berjudul "Analysis of Return on Equity of Kenyan Telecommunication and Technology Industry Using DuPont Model". Penelitian ini menghasilkan kesimpulan bahwa Net Profit Margin, Total Asset Turn Over dan Equity Multiplier bepengaruh positif dan signifikan terhadap Return on Equity. Penelitian terhadulu yang dilakukan oleh Growe, DeBruine, Lee, \& Maldonado pada tahun 2014 yang berjudul "The Profitability and Performance Measurement of U.S. Regional Banks using the Predictive Focus of the "Fundamental Analysis Research". Penelitian ini menghasilkan kesimpulan bahwa variabel makroekonomi, industry specific, Equity to Assets, RCL, Equity Growth, dan Cost to Assets berpengaruh positif dan tidak signifikan terhadap ROE, Expense to Sales Ratio, PCL, NPA, Loan to Assets, Loan Growth berpengaruh negatif dan signifikan terhadap ROE. NCO dan Equity/Loan Growth berpengaruh negatif dan tidak signifikan terhadap ROE. Equity/Asset Growth berpengaruh positif dan signifikan terhadap ROE.

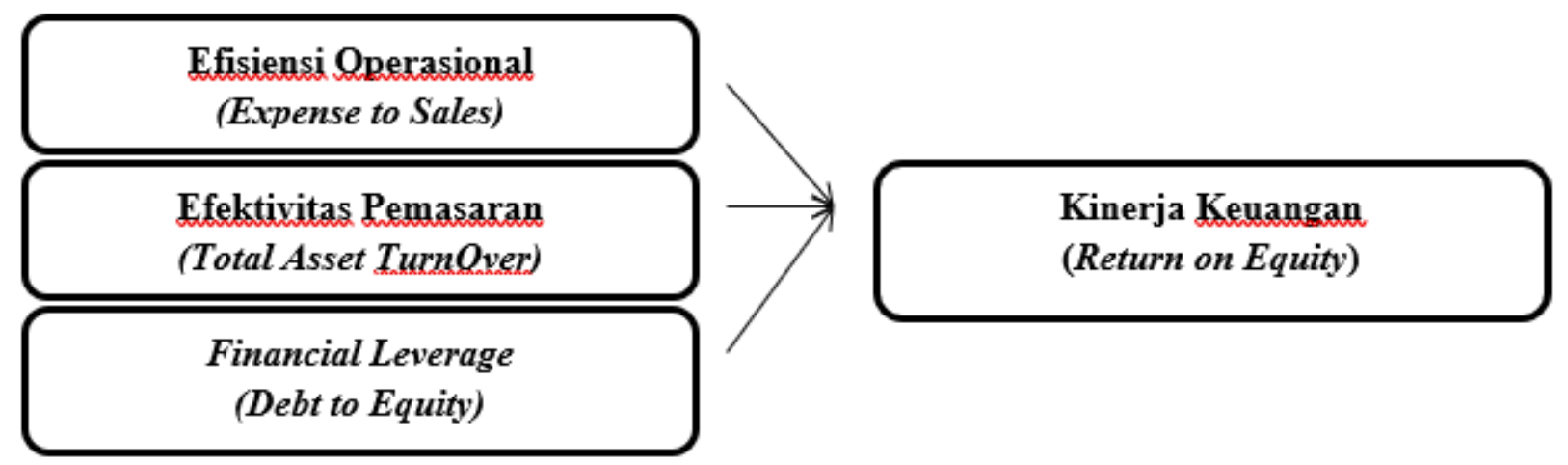

Gambar 2. Model penelitian

Berdasarkan model penelitian diatas, maka dapat disimpulkan hipotesis dalam penelitian ini adalah sebagai berikut:

$\mathrm{H}_{1}$ : Efisiensi Operasional berpengaruh negatif terhadap Kinerja Keuangan.

$\mathrm{H}_{2}$ : Efektivitas Pemasaran berpengaruh positif terhadap Kinerja Keuangan.

$\mathrm{H}_{3}$ : Financial Leverage berpengaruh positif terhadap Kinerja Keuangan.

\section{METODE PENELITIAN}

\section{Populasi}

Penelitian ini dilakukan dengan tujuan untuk mengetahui bagaimana pengaruh efisiensi operasional, efektivitas pemasaran dan financial leverage terhadap kinerja keuangan pada perusahaan subsektor farmasi yang terdaftar di Bursa Efek Indonesia pada tahun 2015 sampai dengan tahun 2019. Subjek dalam penelitian ini adalah perusahaan subsektor farmasi yang terdaftar di Bursa Efek Indonesia pada tahun 2015 - 2019. Penelitian ini menggunakan data yang diperoleh dari situs www.idx.co.id. Perusahaan subsektor farmasi yang digunakan dalam penelitian ini berjumlah 8 perusahaan yang ditunjukkan pada Tabel 1 . 
Tabel 1. Nama perusahaan

\begin{tabular}{|c|c|c|}
\hline $\mathrm{N}_{0}$ & Kode Saham & Nama Perusahaan \\
\hline 1 & DVLA & Darya-Varia Laboratoria Tbk \\
\hline 2 & $\mathrm{KAEF}$ & Kimia Farma (Persero) Tbk \\
\hline 3 & $\mathrm{KLBF}$ & Kalbe Farma Tbk \\
\hline 4 & MERK & Merck Tbk \\
\hline 5 & PYFA & Pyridam Farma Tbk \\
\hline 6 & TSPC & Tempo ScanPacific Tbk \\
\hline 7 & INAF & Indofarma (Persero) Tbk \\
\hline 8 & SIDO & Industri Jamu dan Farmasi Sido Muncul Tbk \\
\hline
\end{tabular}

\section{Operasionalisasi Variabel}

Variabel dependen yang digunakan dalam penelitian ini adalah kinerja keuangan. ROE adalah dasar ukuran dari kinerja keuangan karena ROE diartikan sebagai tingkat pengembalian terhadap modal yang ditanamkan oleh investor dalam persentase yang diproksikan dengan Return on Equity $(\mathrm{ROE})=$ Earning After Tax / Total Equity.

Variabel independen pertama yang digunakan dalam penelitian ini adalah efisiensi operasional. Efisiensi operasional diukur dengan menggunakan rasio Expense to Sales Ratio = total expense $/$ sales, dimana rasio ini mengukur besarnya biaya yang dikeluarkan perusahaan dalam menghasilkan tingkat penjualan tertentu.

Variabel independen kedua yang digunakan dalam penelitian ini adalah efektivitas pemasaran. Efektivitas pemasaran diukur dengan menggunakan rasio Total Asset Turn Over (TATO) = sales I total asset, dimana rasio ini mengukur bagaimana perusahaan memanfaatkan aset yang dimiliki untuk menghasilkan penjualan.

Variabel independen ketiga yang digunakan dalam penelitian ini adalah financial leverage. Financial Leverage diukur dengan menggunakan rasio Debt to Equity Ratio (DER), = total debt $/$ total equity, dimana rasio ini menunjukkan perbandingan antara modal yang digunakan untuk pembiayaan aset perusahaan.

\section{HASIL DAN PEMBAHASAN}

\section{Uji Statistik Deskriptif}

Statistik deskriptif diperoleh melalui pemusatan data (mean, median, nilai minimum dan maksimum, deviasi standar, serta jumlah observasi dari suatu kelompok data) yang digunakan dalam penelitian. 
Tabel 2. Hasil uji statistik deskriptif

\begin{tabular}{|c|c|c|c|c|}
\hline & ROE & ES & TATO & DER \\
\hline Mean & 0.120353 & 0.904205 & 1.109978 & 0.652803 \\
\hline Median & 0.125450 & 0.907200 & 1.139150 & 0.455950 \\
\hline Maximum & 0.301000 & 1.028400 & 1.532700 & 1.806200 \\
\hline Minimum & -0.087900 & 0.707100 & 0.484500 & 0.076100 \\
\hline Std. Dev. & 0.086537 & 0.074229 & 0.254584 & 0.527328 \\
\hline Skewness & -0.345137 & -0.517117 & -0.532584 & 1.120001 \\
\hline Kurtosis & 3.071185 & 2.901372 & 2.678664 & 2.816523 \\
\hline Jarque-Bera & 0.802576 & 1.798947 & 2.063068 & 8.418791 \\
\hline Probability & 0.669457 & 0.406784 & 0.356460 & 0.014855 \\
\hline Sum & 4.814100 & 36.16820 & 44.39910 & 26.11210 \\
\hline Sum Sq. Dev. & 0.292060 & 0.214886 & 2.527705 & 10.84490 \\
\hline Observations & 40 & 40 & 40 & 40 \\
\hline
\end{tabular}

\section{Uji Multikolinearitas}

Uji multikolinearitas bertujuan untuk menguji apakah dalam model regresi panel ditemukan adanya korelasi antar variabel independen. Apabila terjadi koefisien korelasi > 0,80, maka terjadi multikolinearitas. Sebaliknya, jika koefisien korelasi $<0,80$ maka tidak terjadi multikolinearitas (Gujarati,2012:405). Dari pengujian yang telah dilakukan, didapatkan hasil bahwa koefisien korelasi antara Expense to Sales dengan TATO sebesar 0.392359, koefisien korelasi antara Expense to Sales dengan DER sebesar 0.729253, dan korelasi antara TATO dengan DER sebesar -0.118503 secara keseluruhan masing-masing nilai koefisien korelasinya lebih kecil dari 0.8 sehingga hasil pengujian menunjukkan tidak adanya multikolinearitas yang terjadi antar variabel independen yang digunakan dalam penelitian.

\section{Uji Model Regresi Data Panel}

Dalam penelitian ini, model regresi yang paling tepat adalah dengan menggunakan fixed effect model yang didasarkan pada hasil uji Chow, ditemukan bahwa nilai probability cross section chi square sebesar 0.0000 , sehingga dapat disimpulkan bahwa dengan nilai probability cross section chi square: $0.0000<\alpha$ : 0.05 , maka $\mathrm{H}_{0}$ ditolak dan fixed effect model lebih baik digunakan dalam penelitian. Dan berdasarkan hasil uji Hausmann, ditemukan bahwa nilai probability cross section random sebesar 0.0118, sehingga dapat disimpulkan bahwa dengan nilai probability cross section random: $0.0118<\alpha$ : 0.05 , maka $\mathrm{H}_{0}$ ditolak dan fixed effect model lebih baik digunakan dalam penelitian.

\section{Uji Analisis Regresi Berganda}

Berdasarkan hasil pengolahan data yang ada pada Tabel 3, maka dapat disusun persamaan regresi atas penelitian sebagai berikut:

$$
\mathrm{ROE}=0.393425-0.642011 \mathrm{ES}+0.220160 \mathrm{TATO}+0.096606 \mathrm{DER}
$$

Dari persamaan regresi diatas, maka dapat disimpulkan bahwa perusahaan subsektor farmasi dalam meningkatkan ROEnya, maka perusahaan tersebut harus menurunkan nilai Expense to Sales dan meningkatkan nilai TATO dan DER karena berpengaruh positif terhadap ROE, sedangkan Expense to Sales berpengaruh negatif terhadap ROE. Setiap kenaikan sebesar 1 persen pada variabel ES (Expense to Sales) dan variabel lain dikontrol, maka variabel ROE akan menurun sebesar $64.20 \%$. Setiap kenaikan sebesar 1 persen pada variabel TATO dan variabel 
lain dikontrol, maka variabel ROE akan meningkat sebesar 22.02\%. Setiap kenaikan sebesar 1 persen pada variabel DER dan variabel lain dikontrol, maka variabel ROE akan meningkat sebesar 9.66\%. Dan apabila variabel Expense to Sales, TATO, dan DER bernilai 0 maka nilai variabel ROE adalah sebesar 0.393425 .

Tabel 3. Hasil uji analisis regresi berganda

\begin{tabular}{|c|c|c|c|c|}
\hline \multicolumn{5}{|c|}{$\begin{array}{l}\text { Dependent Variable: ROE } \\
\text { Method: Panel Least Squares } \\
\text { Date: } 11 / 30 / 20 \text { Time: } 12: 36 \\
\text { Sample: } 20152019 \\
\text { Periods included: } 5 \\
\text { Cross-sections included: } 8 \\
\text { Total panel (balanced) observations: } 40 \\
\end{array}$} \\
\hline Variable & Coefficient & Std. Error & $\mathrm{t}$-Statistic & Prob. \\
\hline C & 0.393425 & 0.174856 & 2.250000 & 0.0322 \\
\hline ES & -0.642011 & 0.200268 & -3.205764 & 0.0033 \\
\hline TATO & 0.220160 & 0.028320 & 7.774115 & 0.0000 \\
\hline DER & 0.096606 & 0.045156 & 2.139396 & 0.0409 \\
\hline \multicolumn{5}{|c|}{ Effects Specification } \\
\hline \multicolumn{5}{|c|}{ Cross-section fixed (dummy variables) } \\
\hline R-squared & 0.936340 & \multicolumn{2}{|c|}{ Mean dependent var } & 0.120353 \\
\hline Adjusted R-squared & 0.914388 & \multicolumn{2}{|c|}{ S.D. dependent var } & 0.086537 \\
\hline S.E. of regression & 0.025320 & \multicolumn{2}{|c|}{ Akaike info criterion } & -4.286000 \\
\hline Sum squared resid & 0.018592 & & -3.821558 \\
\hline Log likelihood & 96.72001 & \multicolumn{2}{|c|}{ Hannan-Quinn criter. } & -4.118073 \\
\hline F-statistic & 42.65461 & \multicolumn{2}{|c|}{ Durbin-Watson stat } & 1.643270 \\
\hline Prob(F-statistic) & 0.000000 & & & \\
\hline
\end{tabular}

\section{Uji Hipotesis}

Berdasarkan Tabel 3, pengujian nilai t-statistic yang dilakukan dengan menggunakan software Eviews 10 didapatkan nilai signifikansi variabel ES (Expense to Sales) adalah sebesar $0.0033<$ $\alpha$ : 0.05 , artinya $\mathrm{H}_{0}$ ditolak dan Expense to Sales memiliki pengaruh yang signifikan terhadap ROE.

Selanjutnya, adalah nilai signifikansi variabel TATO (Total Asset Turn Over) sebesar $0.0000<$ $\alpha: 0.05$, artinya $\mathrm{H}_{0}$ ditolak dan TATO memiliki pengaruh yang signifikan terhadap ROE.

Nilai signifikansi variabel independen terakhir yaitu DER (Debt to Equity) sebesar $0.0409<\alpha$ : 0.05 , artinya $\mathrm{H}_{0}$ ditolak dan DER memiliki pengaruh yang signifikan terhadap ROE. Pengujian nilai $F$-statistic dilakukan dengan menggunakan software Eviews 10 dan dari pengujian tersebut yang terdapat pada Tabel 3 didapatkan bahwa nilai probability F-Statistic adalah sebesar $0.000000<\alpha$ : 0.05 , artinya $\mathrm{H}_{0}$ ditolak dan terdapat pengaruh yang signifikan antara variabel independen secara simultan dengan variabel dependen.

Bedasarkan Tabel 3, hasil uji koefisien determinasi (Adjusted $R$-squared) dalam analisis regresi panel sebesar 0.914388 atau $91.44 \%$. Artinya, kontribusi variabel independen yaitu efisiensi operasional (Expense to Sales), efektivitas pemasaran (Total Asset Turn Over), dan financial leverage (Debt to Equity) dalam menjelaskan variabel dependen kinerja keuangan perusahaan yang diukur menggunakan Return On Equity adalah sebesar 91.44\%, sedangkan sisanya sebesar $8.56 \%$ dapat dijelaskan oleh variabel lainnya yang tidak digunakan dalam penelitian ini. 


\section{Diskusi}

\section{Efisiensi Operasional (X1) dan Kinerja Keuangan (Y)}

Pengaruh negatif dan signifikan dalam hasil penelitian menjadikan $\mathrm{H}_{1}$ dalam hipotesis penelitian diterima dan sesuai dengan penelitian yang dilakukan oleh Growe, DeBruine, Lee, \& Maldonado pada tahun 2014 bahwa efisiensi operasional memiliki pengaruh negatif terhadap kinerja keuangan. Peningkatan laba menunjukkan bahwa efisiensi operasional berkaitan secara langsung dengan kinerja keuangan yang diukur menggunakan ROE. Ketika efisiensi operasional ditingkatkan yang ditandai dengan menurunnya nilai rasio Expense to Sales, maka semakin besar perolehan laba bagi perusahaan dan artinya semakin tinggi pula tingkat ROE perusahaan.

\section{Efektivitas Pemasaran (X2) dan Kinerja Keuangan (Y)}

Pengaruh positif dan signifikan dalam hasil penelitian menjadikan $\mathrm{H}_{2}$ dalam hipotesis penelitian diterima dan sesuai dengan penelitian yang dilakukan oleh Muchori pada tahun 2018 bahwa efektivitas pemasaran memiliki pengaruh positif terhadap kinerja keuangan. Semakin tinggi nilai penjualan yang dihasilkan atas aset yang dimiliki oleh perusahaan, maka nilai TATO akan semakin tinggi dan semakin besar pula potensi keberhasilan perusahaan untuk memperoleh laba dan meningkatkan kekayaan pemilik perusahaan.

\section{Financial Leverage (X3) dan Kinerja Keuangan (Y)}

Pengaruh positif dan signifikan dalam hasil penelitian menjadikan $\mathrm{H}_{3}$ dalam hipotesis penelitian diterima dan sesuai dengan penelitian yang dilakukan oleh Muchori pada tahun 2018 bahwa financial leverage memiliki pengaruh positif terhadap kinerja keuangan. Nilai DER yang tinggi menunjukkan besarnya penggunaan utang dalam perusahaan yang akan mempengaruhi ROE. Dari hasil analisis data yang telah dilakukan, didapatkan hasil bahwa DER berpengaruh positif terhadap ROE, artinya peningkatan nilai DER atau penambahan utang yang terjadi di dalam perusahaan akan membuat nilai ROE meningkat juga.

\section{KESIMPULAN DAN SARAN}

Penelitian ini dilakukan dengan tujuan untuk mengetahui pengaruh efisiensi operasional, efektivitas pemasaran, dan financial leverage terhadap kinerja keuangan perusahaan subsektor farmasi yang terdaftar di Bursa Efek Indonesia pada tahun 2015 sampai dengan tahun 2019. Penelitian ini menggunakan 8 perusahaan publik subsektor farmasi periode 2015 sampai 2019. Data yang digunakan dalam penelitian ini adalah data sekunder berupa laporan keuangan perusahaan yang diperoleh melalui situs resmi Bursa Efek Indonesia (www.idx.co.id) dan situs resmi yang dimiliki oleh perusahaan. Berdasarkan uraian yang ada pada bab analisis data dan pembahasan, maka kesimpulan dari penelitian ini adalah sebagai berikut:

1. Efisiensi Operasional memiliki pengaruh negatif sebesar $64.20 \%$ yang signifikan terhadap Kinerja Keuangan Perusahaan subsektor farmasi yang terdaftar di BEI periode 2015-2019.

2. Efektivitas Pemasaran memiliki pengaruh positif sebesar $22.02 \%$ yang signifikan terhadap Kinerja Keuangan Perusahaan subsektor farmasi yang terdaftar di BEI periode 2015-2019.

3. Financial Leverage memiliki pengaruh positif sebesar $9.66 \%$ yang signifikan terhadap Kinerja Keuangan Perusahaan subsektor farmasi yang terdaftar di BEI periode 2015-2019.

Keterbatasan dalam penelitian ini dapat dirangkum melalui saran yang dapat diberikan. Berikut adalah saran atas penelitian yang dilakukan:

a. Bagi Akademis dan Peneliti Lain

Penelitian selanjutnya dapat menggunakan lebih banyak variabel inpenden, lebih banyak sampel perusahaan, dan lebih banyak tahun periode yang digunakan untuk penelitian agar dapat melihat pengaruhnya secara lebih luas. Dan juga, penelitian selanjutnya dapat mengembangkan biaya apa saja yang mempengaruhi ROE dalam efisiensi operasional. 
b. Bagi Perusahaan

Berdasarkan hasil penelitian yang ada dapat disimpulkan bahwa efisiensi operasional, efektivitas pemasaran, dan financial leverage berpengaruh signifikan terhadap kinerja keuangan perusahaan, sehingga untuk meningkatkan kinerja keuangan perusahaan dapat dilakukan dengan meningkatkan efisiensi operasional melalui penekanan biaya, meningkatkan efektivitas pemasaran, dan menggunakan financial leverage yang baik dan sesuai dengan kebutuhan perusahaan.

c. Bagi Investor

Penelitian ini menunjukkan tingkat kinerja keuangan perusahaan subsektor farmasi di Indonesia dari tahun 2015 sampai dengan tahun 2019. Dengan peningkatan kinerja keuangan yang didorong oleh efisiensi operasional, efektivitas pemasaran, dan financial leverage maka hal tersebut mengindikasikan bahwa nilai buku dari perusahaan tersebut baik, sehingga ditengah kondisi subsektor yang akan terus berkembang dan menjadi salah satu sektor penopang dalam perekonomian, maka nilai buku dari perusahaan akan mampu menjadi cerminan atas nilai pasar perusahaan di masa yang akan datang dan diharapkan dapat menjadi pertimbangan bagi investor dalam melakukan investasi.

\section{REFERENSI}

Bhama, V., Jain, P. K., \& Yadav, S. S. (2016). Testing the pecking order theory of deficit and surplus firms: Indian evidence. International Journal of Managerial Finance.

Brigham, E. F., \& Ehrhardt, M. C. (2017). Financial Management: Theory \& Practice. Cengage Learning.

Delen, D., Kuzey, C., \& Uyar, A. (2013). Measuring firm performance using financial ratios: A decision tree approach. Expert Systems with Applications.

Drucker, P. F., \& Collins, J. (2017). The Effective Executive: The Definitive Guide to Getting the Right Things Done. Harper Business.

Ghozali, I., (2017). Aplikasi Analisis Multivariate dan Ekonometrika dengan Eviews. 2 ed. Semarang: BPFE Universitas Diponegoro.

Gitman, L. J., \& Zutter, C. J. (2015). Principles of Managerial Finance 14th Edition. Harlow: Pearson Education.

Gujarati, D. N., (2012). Dasar-dasar Ekonometrika. 5 ed. Jakarta: Salemba Empat.

Husnan, Suad. Manajemen Keuangan (Teori dan Penerapan). Edisi Keempat. BPFE, Yogyakarta. 2000.

Ross, S. A., Westerfield, R. W., Jaffe, J., \& Jordan, B. D. (2016). Corporate Finance: 11th Edition. New York: McGraw Hill Education.

Weidman, S. M., McFarland, D. J., Meric, G., \& Meric, I. (2018). Determinants of return-onequity in USA, German and Japanese manufacturing firms. 